life at Agra. Dr. Hankin's earlier researches before proceeding to India were mainly concerned with the germicidal action of proteins of blood-serum and of cells, so-called 'alexins', upon which he published several papers in the Proceedings of the Royal Society, Journal of Pathology and Bacteriology and Centralblatt für Bakteriologie.

In India, Hankin soon took up the study of cholera, isolated the cholera vibrio from contaminated well- and river-water, and so early as 1894 insisted that the disease was a microbial one and not a 'miasm'. He studied methods for destroying microbes, particularly the cholera vibrio, in the contaminated water of wells, first by means of excess of lime, and afterwards with permanganate of potash, and his method of "pinking" wells continued in use until the introduction of chlorination. In connexion with cholera, he noted that the waters of the Jumna and Ganges possessed a natural germicidal action upon the vibrio, which was not removed by filtration but was destroyed by boiling, but in spite of much work on the subject, he was unable to discover the nature of the germicidal agent. This was not elucidated until many years later through the work of Twort and of d'Hérelle upon the filterable lytic agent that destroys bacteria, the bacteriophage. Hankin also published several papers dealing with plague, the plague bacillus, and the relation of insects and rats to its spread.

Besides his bacteriological work, Dr. Hankin's other pursuits included observations upon the problems of flight, studied mathematically, experimentally with kites, and by observations on the flight of tirds, which were embodied in a small work "Animal Flight". He also published "Methods of Design in Mahomedan Art", an analysis of geometric patterns, especially of those that adorn the Taj Mahal.

R. T. HEWLETT.

\section{Prof. Ettore Pais}

WE regret to record the death of Prof. Ettore Pais which took place recently in Rome at the age of eighty-three years. Prof. Pais was a historian of international reputation, widely known as one of the foremost authorities on the history, laws and customs of ancient Rome and the early history of the peoples of the Italian peninsula generally.

Ettore Pais was born in 1856 and educated at the University of Florence, afterwards studying under Mommsen in Berlin. His first appointment on his return to Italy was as curator of the museum at Cagliari. Afterwards he occupied the chair of ancient history in the University of Palermo. In 1906 he was appointed to the University of Rome, after holding professorial chairs at Pisa and Naples. In Rome the researches in archæology and the early history of Roman rule, which he had initiated when in Sardinia, Sicily and southern Italy in his earlier years, came to full fruition. During his twenty-five years tenure of his chair, his lectures and writings on the epigraphy, antiquities and prehistory of Italy and on the history of Rome up to the Punic wars came to be recognized as of standard authority, more especially for the insight displayed in his brilliant interpretations of the results of the excavations of Roman and Etruscan antiquities.

Among the honours which Pais received were honorary doctorates of the Universities of Oxford, Paris and Chicago, membership of the Institut de France, and in 1922 elevation to the rank of senator.

\section{Miss Ella C. Sykes}

WE regret to record the death of Miss Ella Constance Sykes, which took place in London on March 23. Miss Sykes, who was educated at Lady Margaret Hall, Oxford, had been secretary of the Royal Asiatic Society (1920-26), and was a member of the Royal Geographical and Central Asian Societies, at whose meetings she was well known as a traveller with first-hand and intimate knowledge of the land and peoples of Persia in the earlier years of the century. She accompanied her brother, Major (afterwards Brigadier-General Sir) Percy Molesworth Sykes, on journeys of geographical and archæological interest, made when he was seconded from the British Army in India to the consular service and was ConsulGeneral in Kerman. On one occasion she and her brother rode on horseback from the Caspian to India, and in 1915 they travelled together in Chinese Turkestan and the Pamirs. Her experiences in Persia were embodied in "Through Persia on a Side-saddle" and in "Persia and her People". She was also joint author with her brother of "Through Deserts and Oases of Central Asia". Miss Sykes visited Canada to investigate the question of the employment of educated women there on behalf of the Colonial Intelligence League. "A Home-Help in Canada" records her experiences.

WE regret to announce the following deaths :

Dr. J. Anderson, formerly lecturer in bee-keeping in the North of Scotland College of Agriculture, aged sixty-six years.

Prof. W. Cramp, professor of engineering in the University of Birmingham, on April 20, aged sixtythree years.

Mr. E. W. Fraser-Smith, secretary and treasurer of the North East Coast Institution of Engineers and Shipbuilders since 1911, on April 5.

Mr. H. J. George, University lecturer in chemistry in the University of Oxford, an April 19.

Prof. F. N. Guild, emeritus professor of geology and mineralogy in the University of Arizona, on March 12, aged sixty-eight years.

Captain H. M. S. Laidlaw, known for his work on hydrography and in re-surveying small islands in the South Seas, on April 16, aged fifty-two years.

The Rev. W. J. O'Leary, S.J., director of Riverview Observatory since 1929, known for his work in seismology and astronomy, aged seventy years.

Sir William Ramsay, emeritus professor of humanity in the University of Aberdeen, formerly professor of classical archæology and art in the University of Oxford, on April 20, aged eighty-eight years. 